\title{
Do Socioeconomic Factors Matter in Acreage Owned and Acreage Farmed by Small Livestock Producers in Georgia?
}

\author{
David Nii O. Tackie ${ }^{1}$, Jannette R. Bartlett ${ }^{1}$, Akua Adu-Gyamfi ${ }^{1}$, Nicole I. Nunoo ${ }^{1} \&$ Bridget J. Perry $^{1}$ \\ ${ }^{1}$ College of Agriculture, Environment and Nutrition Sciences, Tuskegee University, Tuskegee, AL, USA \\ Correspondence: David Nii O. Tackie, College of Agriculture, Environment and Nutrition Sciences, Tuskegee \\ University, Tuskegee, AL 36088, USA. Tel: 1-334-727-8813. E-mail: dtackie@tuskegee.edu
}

Received: May 21, 2020

Accepted: July 1, $2020 \quad$ Online Published: July 15, 2020

doi:10.5539/jas.v12n8p42

URL: https://doi.org/10.5539/jas.v12n8p42

The research is financed by USDA National Institute of Food and Agriculture.

\begin{abstract}
Although socioeconomic factors may influence acreage owned and acreage farmed by small producers, limited studies have been conducted on this topic in the Southeastern U.S., such as in Georgia. Therefore, the study ascertained the effect of socioeconomic factors on acreage owned and acreage farmed by small livestock producers in Georgia. The data were obtained from a sample of producers, and assessed by using descriptive statistics and ordinal logistic regression analysis. The findings revealed that a majority had farming experience and livestock farming experience of 30 years or less, respectively, 82 and $77 \%$. Corresponding proportions for 20 years or less were 74 and $71 \%$. Additionally, a little less than half $(48 \%)$ owned over 60 acres of land, and a majority (55\%) farmed over 60 acres. The ordinal logistic regression analyses revealed that, of the socioeconomic factors, farming status, education, and household income had statistically significant effects on acreage owned and acreage farmed. The findings suggest that socioeconomic factors matter in farm size in the study area, and they should be taken into consideration when designing programs for small producers.
\end{abstract}

Keywords: socioeconomic factors, acreage owned, acreage farmed, small livestock producers, small producers

\section{Introduction}

Farm size is important in matters related to small producers. MacDonald, Hoppe, and Newton (2017) emphasized that farm size can be measured in various ways. One common way is acreage, but this varies according to quality. Consequently, production from a particular land size can vary with its quality, use, and with inputs. They explained that land size is not a good indicator for farm size regarding livestock activities, and that the number of heads of livestock or annual sales is a better indicator. They further explained that the USDA ERS often uses farm sales (gross cash farm income-GCFI) to reflect farm size, and to capture input use. Nonetheless, they argued, land in acres is still important, especially looking at cropland acreage.

The Livestock and Poultry Environmental Learning Community (LPELC) $(2019$, p. 1) focused on the farm classification of the USDA ERS. It stated that farms are generally classified into 8 categories, namely, "(1) retirement farms - small farms whose operators report they are retired; (2) residential/lifestyle farms - small farms whose operators report a major occupation other than farming; (3) farming occupation farms-family farms, whose operators report farming as their major occupation; (4) low-sales farms-gross sales less than $\$ 100,000$; (5) high-sales farms - gross sales between $\$ 100,000$ and 249,999 ; (6) large family farms — gross sales between $\$ 250,000$ and 449,999 ; (7) very large family farms - gross sales of $\$ 500,000$ or more, and (8) nonfamily farms - any farm not classified as a family farm; the majority of the farm business is not owned by individuals related by blood, marriage, or adoption". These are normally collapsed into three categories; 1 and 2 , as rural residence family farms; 3,4 , and 5 , as intermediate family farms, and 6,7 , and 8 , as commercial farms. In other words, these three sets of farms may be classified as small, medium, and large.

USDA NASS (2016), based on the $2012 \mathrm{Ag}$ Census, also reported that $88 \%$ of all farms were small farms with less than $\$ 350,000$ GCFI. It reported two main groupings and overall, four types of small family farms; specifically, (1) farms whose operator has a main occupation apart from farming; (2) farms whose operator has farming as his or her main occupation; this comprises farms with (a) low sales-annual GCFI is less than 
$\$ 150,000$; (b) moderate sales - annual GCFI is $\$ 150,000$ to 349,000 , and (c) retirement farms - the operator is retired but he or she is farming on a small scale. According to the USDA NASS (2019a), land in farms decreased by $40 \%$ and accounted for a little over $2 \mathrm{~m}$ acres in 2017 , a decrease of $14.3 \mathrm{~m}$ acres compared to 2012 . The average farm size, in addition, increased from 434 acres in 2012 to 441 acres in 2017 (i.e., a 1.6\% increase). Also, it reported that within the same period, only two sets of farms increased in number; these were the smallest farms (less than 10 acres) and largest farms (2,000 acres or more). The Agency also revealed that $42 \%$ of small-sized farms (i.e., those less than 50 acres) possessed $2 \%$ of the farmland; however, $13 \%$ of these farms (i.e., those less than 10 acres) possessed less than $1 \%(0.14 \%)$ of the farmland in the U.S.

Furthermore, Maixner and Wyant (2019) stressed that from the 1930s to date, the average farm size has increased and at the same time, the number of farms has decreased. They also reiterated that mid-sized farms were decreasing the quickest and two farm types were emerging, namely, smaller farms with direct-to-consumer marketing focus, and larger operations, which go through "traditional channels". Newton (2014) also observed that the number of smaller (less than $\$ 10,000$ sales, or less than 50 acres) and larger farms (greater than $\$ 250,000$ sales, or greater than 2,000 acres) had increased, and the number of mid-sized farms $(\$ 10,000-250,000$ sales, or 50-2,000 acres) had decreased. Newton offered four main reasons for this development, specifically, (1) large farms have better financial performance, on average, than small farms; (2) the number of persons seeking to enjoy rural lifestyles keeps increasing, and these persons are opting to farm; (3) the definition of a farm using $\$ 1,000$ sales as a threshold allows more farms to be captured; and (4) the USDA NASS' effort to capture many more small farmers in the Census makes their representation more obvious.

Moreover, USDA NASS (2019b) indicated that nearly 77,000 (or 4\%) of farms made \$1m or more in 2017 and about $1.6 \mathrm{~m}$ farms made under $\$ 50,000$; however, 792,000 (or nearly $39 \%$ ) made less than $\$ 2,500$. Roughly, two-thirds of the total value of production of about $\$ 389 \mathrm{bn}$ came from farms making $\$ 1 \mathrm{~m}$ or more. It appears small farmers have always earned low revenues. For instance, Thompson (1986) also stressed that although small producers are the majority of U.S. producers, half of small farms had gross revenues of less than $\$ 5,000$ per year and one-third grossed less than $\$ 25,000$ per year. Additionally, he emphasized that small producers come in different forms; there are the traditional full-time family producers; subsistence producers, especially, minority producers in the South; retirees moving towards reducing operations or those who have gone back to farming, and very small producers, who are part-time producers, with off-farm employment, full-time or part-time.

Small producers and/or small farms are important to agricultural production in the U.S. Again, Thompson (1986) maintained that small producers are a bedrock of many rural communities. Even today, we also argue that small producers play a vital role in the agricultural supply chain and enhance the vitality of rural communities. They do so by selling products locally; thus, keeping dollars in the local community, creating social interaction between them and their customers, who are usually from the community. Also, Khalil, Conforti, Ergin, and Gennari (2017) provided several criteria for defining who a small farmer is. They mentioned land size, labor input, family farming, market orientation, economic size, and multiple criteria. In this paper, the first criterion is the one in mind, where it is "a threshold of land size (or number of livestock) under which the farm is considered small." However, in our case, we focus on acreage only. What is more, this group of producers (we have in mind) usually farm on small acreages; that is, their farm sizes are smaller compared to other producers. Farming on small acreages may be affected by socioeconomic factors. Indeed, acreage owned and acreage farmed are two such indices that could be affected; they are both related to farm size. Yet, limited studies have been conducted on the subject. One group of small producers for whom this is germane is small livestock producers in the Southeast, for example, Georgia being a case in point. Based on the preceding, there is a need to ascertain the effects of socioeconomic factors on farm size for small livestock producers in this region. Therefore, the purpose of the study was to examine the impact of socioeconomic factors on acreage owned and acreage farmed by small livestock producers in Georgia. The objectives are to (1) identify and describe socioeconomic and other factors, and (2) estimate the extent to which socioeconomic factors affect acreage owned and acreage farmed. Insofar as we know, only one study, Tackie, Bartlett, and Nunoo (2019), has assessed the effect of socioeconomic factors on farm size of small producers, and this study is patterned after that study.

\section{Literature Review}

A number of authors have researched farm size in relation to other factors. Not many, if any, have researched the topic from the point of view of the impact of socioeconomic factors on farm size or acreage owned and acreage farmed. Consequently, a selection of the aforementioned studies are briefly discussed chronologically. For example, Richardson and Condra (1981) evaluated farm size in the El Paso Valley focusing on survival/success. Data were developed on representative farms using primary and secondary sources. Four farm sizes were used: 
$160,320,640$, and 960 acres; three beginning equity levels were used: 25,50 , and $100 \%$, and three land tenure scenarios were used: full ownership, mix of ownership and lease, and full lease. In the study, farm size referred to total acres farmed. The authors analyzed the data using simulation techniques. The results showed that the projected chances of survival and success increased as farm size increased from 160 to 960 acres and/or beginning equity level increased from 25 to $100 \%$. In other words, at least, the greater the farm size and beginning equity level, the greater the chance of survival or success in the study area.

Furthermore, van Zyl, Binswanger, and Thirtle (1995) examined the relationship between farm size and efficiency in South African Agriculture. The data were collected from farmer households, using a survey. The authors used data envelopment analysis to measure efficiency. They found that small farms in the homelands (i.e., deprived areas without government support) were scale inefficient. However, in the commercial farming areas, there was an inverse relationship between farm size and efficiency. The inverse relationship was even stronger when policy distortions, which favored larger farms were removed; larger farms used more capital compared to smaller farms and smaller farms used more labor than larger farms. Also, managerial ability was associated with farm size (i.e., the more astute managers had the larger farms). In other words, it is possible for a smaller farm to be efficient if the appropriate strategies, or policies, are used.

Moreover, Weiss (1999) assessed farm growth and survival for individual farms in Upper Austria. They used panel data of farm households, and analyzed the data by probit analysis and ordinary least squares regression. Farm growth was the dependent variable and other variables such as, off-farm employment, family size, age, gender, education, and farm size were independent variables. Farm size was measured as acres under cultivation and number of livestock. They found that age, education, gender, family size, off-farm employment, and farm size had statistically significant effects on farm growth and survival.

Additionally, Helfand and Levine (2004) examined farm size and the determinants of productive efficiency in the Brazilian Center-West. They obtained data from the Brazilian Ag Census, and categorized farms into small, medium, and large. They analyzed the data using data envelopment analysis and generalized least square regression. The results showed that the relationship between farm size and efficiency was not linear; specifically, they found that, efficiency initially declined, and then rose with increases in farm size. The authors indicated that the key reason for this phenomenon was preferential treatment given to large farms. Such treatment resulted in positive growth in productivity, and therefore, efficiency. According to them, if such treatment were given to smaller farms (small- and mid-sized), then these farms could produce with equal efficiency, if not more efficiently than the larger farms.

Also, Mburu, Ackello-Ogutu, and Mulwa (2014) analyzed economic efficiency and farm size of wheat farmers in Nakuru District, Kenya. They obtained data from a random sample of farmers, and analyzed the data by ordinary least squares regression, using a Cobb Douglas function, and Tobit regression model. For the Cobb Douglas function, the dependent variable was cost of production and the independent variables were wheat output per acre, price of fertilizer, price of seeds, price of chemical, wage rate, and family labor. For the Tobit regression, the dependent variable was the particular farm and the independent variables were socioeconomic factors, such as age, gender, education, marital status, occupation, farmer group, land tenure, and distance to extension services. The authors reported that the mean technical, allocative, and economic efficiency indices of small-sized wheat farmers were, respectively, 85, 95, and $84 \%$. Related values for large-sized farmers were, respectively, 91, 94, and $88 \%$. The results showed that small farms can produce efficiently. Additionally, education, distance to extension services, and farm size had statistically significant effects on efficiency.

Further, Anigbogu, Agasi, and Okoli (2015) investigated socioeconomic factors influencing agricultural production among cooperative farmers in Anambra State, Nigeria. They used multistage sampling techniques, including judgmental and random sampling, to collect data from farmers. They used ordinary least squares regression analysis to analyze the data with output as the dependent variable and a set of independent variables, including gender, age, marital status, education, farming experience, farm size, household size, income, credit obtained, seedling obtained, fertilizer obtained, type of technology, soil fertility, and crop type. They found that gender, age, education, and income had positive and significant effects on farmers' output. On the contrary, although farm size was not significant, it had a positive effect on farmers' output.

Relatedly, Sheng, Zhao, Nossal, and Zhang (2015) evaluated productivity and farm size in Australian Agriculture. The authors obtained data from the Australian Agricultural Grazing Industries Survey, primarily, data on outputs, inputs, and farm sizes. They used Cobb Douglas production function and ordinary least squares regression. The dependent variable was output and the independent variables were inputs used and farm sizes; farms were categorized into small, medium, and large. The results showed that larger farms were more productive than 
smaller farms. In particular, medium farms and large farms, on average, respectively, produced 32 and $54 \%$ higher output than small farms. They explained that differences in production technologies may be responsible for this outcome; hence, they suggested that small farms should focus on accessing appropriate technologies rather than seeking to expand in size.

In addition, Tackie, Adu-Gyamfi, Bartlett, McKenzie-Jakes, and Perry (2018) examined the characteristics and practices of selected Florida small livestock producers looking at economic and marketing issues. The authors obtained data using a survey, and conducted analysis by descriptive statistics. They found that the respondents were made up of a higher proportion of part-time producers than full-time producers; a higher proportion of female producers than male producers, and a higher proportion of White producers than Black producers. What is more, there were more respondents who were 45 years or older than compared to those who were younger than 45 years; more respondents who had at most some college education than those who had higher levels of education, and more respondents earned at most $\$ 40,000$ as annual household income than those who earned over $\$ 40,000$ as annual household income. The findings also revealed that a majority $(74 \%)$ had 20 years or less farming experience; $71 \%$ had 20 years or less livestock farming experience; $61 \%$ owned more than 20 acres of land, and $69 \%$ farmed more than 30 acres of land $(69 \%)$. Since the producers farmed more acreage than the owned, the authors concluded that these producers may be leasing additional acreage.

Consequently, Tackie et al. (2019) assessed acreage owned and acreage farmed in relation to socioeconomic factors in Alabama. They collected data by interviews using a questionnaire, and analyzed the data using descriptive statistics and ordinal logistic regression analysis. They also reported that there were more part-time than full-time producers; more male producers than female producers, and more Black producers than White producers. Again, there were more respondents 45 years or older than younger; more respondents with at most some college education than those with higher education, and more producers with at most $\$ 40,000$ as annual household income than those with higher income. The findings, further, revealed that a majority (58\%) had more than 30 years farming experience; owned more than 50 acres of land $(61 \%)$, and farmed more than 50 acres of land $(69 \%)$. Here again, more land was farmed than rented. Additionally, they found that age and education had positive and statistically significant effects on acreage owned and acreage farmed.

The literature discussed above, can be summarized in three categories. First, survival or success (Richardson \& Condra, 1981; Weiss, 1999). Second, efficiency and efficiency-related issues (van Zyl, Binswanger, \& Thirtle, 1995; Helfand \& Levine, 2004; Mburu, Ackello-Ogutu, \& Mulwa, 2014; Anigbogu, Agasi, \& Okoli, 2015; Sheng, Zhao, Nossal, \& Zhang, 2015). Third, socioeconomic factors, related factors, and farm size (Tackie, Adu-Gyamfi, Bartlett, McKenzie-Jakes, \& Perry, 2018; Tackie, Bartlett, \& Nunoo, 2019). The latter two studies are more closely related to the current study than the other studies. Thus, emphasizing the paucity of research on the subject matter; hence, the quest to embark on the current study.

\section{Methodology}

\subsection{Data Collection}

This study was undertaken by initially developing a questionnaire made up of six sections, including farm information, production, processing, economics, marketing, and demographic information. The questionnaire was revised several times and was sent to the Institutional Review Board of the researchers' Institution for review and approval. After approval was granted, it was administered to a convenience sample of small livestock producers. The reason why this method was used is because there was not an available sampling frame from which the subjects of interest could be drawn.

The data were obtained via interviews of small beef cattle and meat goat producers at several program sites in Georgia and the producers came from fourteen Georgia counties: Carroll, Fulton, Hall, Madison, Polk (North), Bibb, Crawford, Macon, Peach, (Central), Brooks, Colquitt, Lanier, Lowndes, and Tattnall (South). The interviews were conducted from the summer of 2013 to the spring of 2016. Those who conducted the interviews were made up of Extension agents and other personnel in the various counties, as well as graduate students. The initial total sample size was 40 , which was considered adequate for the study. Only some of the data collected was used in this study, as it is part of a larger study on small producer activities in three southeastern states. This particular study is the second study of three identical studies dealing with the same subject matter in the region by the researchers. 


\subsection{Data Analysis}

We analyzed the data using descriptive statistics and ordinal logistic regression analysis. We used a modified logistic regression model, adapted from Banterle \& Cavaliere (2009), and which was also used in Tackie et al. (2019, pp. 5-6), as follows:

$$
\mathrm{C}_{\mathrm{j}}\left(\mathrm{X}_{\mathrm{i}}\right)=\ln \left[P\left(\mathrm{Y}>\mathrm{j} \mid \mathrm{X}_{\mathrm{i}}\right) / P\left(\mathrm{Y} \leq \mathrm{j} \mid \mathrm{X}_{\mathrm{i}}\right)\right]=\beta_{1} \mathrm{X}_{\mathrm{i} 1}+\ldots+\beta_{\mathrm{ik}} \mathrm{X}_{\mathrm{ik}}-\tau_{\mathrm{j}}+1
$$

where, $\mathrm{C}_{\mathrm{j}}\left(\mathrm{X}_{\mathrm{i}}\right)$ is the cumulative odds of being at or below category $\mathrm{j}$ of an ordinal variable with $\mathrm{K}$ categories, $1 \leq \mathrm{j}$ $\leq \mathrm{K}-1$; i is the number of participants/producers considered; $\mathrm{j}$ is the score for a category (of $\mathrm{Y}$ ); $\mathrm{k}$ is the number of independent variables; $\mathrm{Y}$ is the dependent variable; $\mathrm{X}_{\mathrm{ij}}$ represents the independent variables; $\beta_{\mathrm{i}}$ represents the coefficients, and $\tau$ represents the cut points between categories of the dependent variable.

As mentioned previously, the original total sample size was 40; but, for the ordinal logistic regression analysis, the number of observations used was 29 , because of eliminating some observations with "no responses." This is acceptable as far as the number of observations reasonably exceed the number of independent variables (Gujarati and Porter, 2009). Acreage farmed was considered to be associated with acreage owned. The reason is normally, acreage farmed is related to acreage owned. With this in mind, acreage farmed reflects "actual farm size." Consequently, both indicators are linked to farm size. Based on the aforementioned explanations, two estimation models were generated and used for the study. The estimation model for model 1 is:

$$
\ln (P A C O>\mathrm{j} / P A C O \leq \mathrm{j})=\beta_{1} \mathrm{FST}+\beta_{2} \mathrm{GEN}+\beta_{3} \mathrm{RAE}+\beta_{4} \mathrm{AGE}+\beta_{5} \mathrm{EDU}+\beta_{6} \mathrm{HHI}-\tau+1
$$

where, $\ln (P A C O>\mathrm{j} / P A C O \leq \mathrm{j})$ is cumulative odds of being at or below an acreage owned (ACO) category; FST is farming status; GEN is gender; RAE is Race/ethnicity; AGE is Age; EDU is Education, and HHI is Household income. The socioeconomic factors were chosen by the researchers based on experience dealing with these producers in the region for over 20 years. It has been observed that farming status, gender, race/ethnicity, age, education, and annual household income play a major role in how small farmers engage in their farming operations.

In summary, estimation model 1 hypothesizes that acreage owned is affected by farming status, gender, race/ethnicity, age, education, and household income. The overall null hypothesis is that all of the regression coefficients are equal to zero or the independent variables together do not affect acreage owned. The hypothesized signs were as follows: farming status $(+/-)$; gender $(+/-)$; race/ethnicity $(+/-)$; age $(+)$; education $(+)$, and household income $(+)$. These mean that full-time producers will own more acreage; male producers will own more acreage; White producers will own more acreage; older producers will own more acreage; more educated producers will own more acreage; higher household income producers will own more acreage. The specifics of the variable names and descriptions used for model 1 are shown in Appendix A.

An identical model, model 2, was set up for acreage farmed as:

$$
\ln (P A C F>\mathrm{j} / P A C F \leq \mathrm{j})=\beta_{1} \mathrm{FST}+\beta_{2} \mathrm{GEN}+\beta_{3} \mathrm{RAE}+\beta_{4} \mathrm{AGE}+\beta_{5} \mathrm{EDU}+\beta_{6} \mathrm{HHI}-\tau+1
$$

where, $\ln (P A C F>\mathrm{j} / P A C F \leq \mathrm{j})$ is cumulative odds of being at or below an acreage farmed (ACF) category; FST is Farming status; GEN is Gender; RAE is Race/ethnicity; AGE is Age; EDU is Education, and HHI is Household income.

In short, estimation model 2 hypothesizes that acreage farmed is affected by farming status, gender, race/ethnicity, age, education, and household income. Here, as well, the overall null hypothesis is that all of the regression coefficients are equal to zero or the independent variables together do not affect acreage farmed. Just as in the acreage owned case, the hypothesized signs were as follows: farming status (+/-); gender (+/-); race/ethnicity (+/-); age $(+)$; education $(+)$, and household income $(+)$. Identical explanations for the expected signs hold for acreage farmed as for acreage owned. The specifics of the variable names and descriptions used for model 2 are also reported in Appendix A. The descriptive analysis for the variables and ordinal logistic regression analysis were run for the models, using SPSS $12.0^{\circ}$ (MapInfo Corporation, Troy, NY). The criteria used to evaluate both models were the model chi-square, beta coefficients, and $p$ values.

\section{Results and Discussion}

Tables 1 and 2 reflect the descriptive results, while Tables 3 and 4 reflect the regression results. Even though Tables 1 and 2 depict the descriptive results, and have been shown in other studies associated with the larger study, they are reiterated here to provide context. Table 1 shows the socioeconomic characteristics of the respondents. Most of the respondents were full-time (50\%); were females $(55 \%)$, and were Whites $(55 \%)$. As well, most (38 and 40\%, respectively) were in the $45-64$ and 65 years or older age ranges; relatedly, $63 \%$ were 55 years or older. Also, $53 \%$ had some college education or lower, and $45 \%$ had at least a college degree. 
Additionally, $15 \%$ had an annual household income of $\$ 40,000$ or less, and $25 \%$ had an annual household income of more than $\$ 40,000$ but less than $\$ 60,000 ; 38 \%$ reported over $\$ 60,000$ annual household income. Selected results, age and education, agree with Tackie et al. (2019) for Alabama who reported that there were more producers in the 45 years or higher age ranges than other age ranges, and more producers with at most some college education. However, some of the results of this study are contrary to some of the findings of the Tackie et al. (2019) study, where there were more part-time than full-time producers; more male than female producers; more Black than White producers, and more producers with an annual household income of $\$ 40,000$ or less than over $\$ 40,000$. Moreover, the results are consistent with Tackie et al. (2018) for Florida, who also reported more White producers than Black producers; more producers in the 45 years or higher age ranges than other age ranges; more producers with at most some college education than higher levels of education. On the contrary, the findings are in opposition to Tackie et al. (2018) for Florida, where there were more part-time producers than full-time producers, and more producers with at most an annual household income of $\$ 40,000$ than over $\$ 40,000$.

Table 2 presents farm characteristics of the producers. Nearly $63 \%$ had livestock operations only, and 33\% had mixed enterprises of both livestock and crop production; 35\% had farming experience of at most 15 years; $48 \%$ had farming experience 16-30 years, and 18\% had farming experience of more than 30 years. The experience with livestock reflected an almost identical trend; 30\% had livestock farming experience of at most 15 years; $48 \%$ had livestock farming experience of 16-30 years, and 23\% had livestock farming experience of more than 30 years. In short, $82 \%$ had farming experience of at most 30 years, and $18 \%$ had farming experience of more than 30 years.

Table 1. Socioeconomic characteristics $(\mathrm{N}=40)$

\begin{tabular}{|c|c|c|}
\hline Variable & Frequency & Percent \\
\hline \multicolumn{3}{|l|}{ Farming Status } \\
\hline Full-time & 20 & 50.0 \\
\hline Part-time & 19 & 47.5 \\
\hline No Response & 1 & 2.5 \\
\hline \multicolumn{3}{|l|}{ Gender } \\
\hline Male & 17 & 42.5 \\
\hline Female & 22 & 55.0 \\
\hline No Response & 1 & 2.5 \\
\hline \multicolumn{3}{|l|}{ Race/Ethnicity } \\
\hline Black & 14 & 35.0 \\
\hline White & 23 & 57.5 \\
\hline Other & 1 & 2.5 \\
\hline No Response & 2 & 5.0 \\
\hline \multicolumn{3}{|l|}{ Age } \\
\hline $20-24$ years & 0 & 0.0 \\
\hline 25-34 years & 1 & 2.5 \\
\hline $35-44$ years & 5 & 12.5 \\
\hline $45-54$ years & 6 & 15.0 \\
\hline 55-64 years & 9 & 22.5 \\
\hline 65 years or older & 16 & 40.0 \\
\hline No Response & 3 & 7.5 \\
\hline \multicolumn{3}{|l|}{ Educational Level } \\
\hline High School Graduate or Below & 9 & 22.5 \\
\hline Two-Year/Technical Degree & 7 & 17.5 \\
\hline Some College & 5 & 12.5 \\
\hline College Degree & 7 & 17.5 \\
\hline Post-Graduate/Professional Degree & 11 & 27.5 \\
\hline No Response & 1 & 2.5 \\
\hline
\end{tabular}




\begin{tabular}{lll}
\hline Annual Household Income & & \\
$\$ 10,000$ or less & 0 & 0.0 \\
$\$ 10,001-20,000$ & 1 & 2.5 \\
$\$ 20,001-30,000$ & 2 & 5.0 \\
$\$ 30,001-40,000$ & 3 & 7.5 \\
$\$ 40,001-50,000$ & 6 & 15.0 \\
$\$ 50,001-60,000$ & 4 & 10.0 \\
Over $\$ 60,000$ & 15 & 37.5 \\
No Response & 9 & 22.5 \\
\hline
\end{tabular}

Similarly, $77 \%$ had livestock farming experience of at most 30 years, and $23 \%$ had livestock farming experience of more than 30 years. However, $63 \%$ had over 20 years farming experience, and $58 \%$ had over 20 years livestock farming experience. Although the proportion of producers with livestock farming experience of more than 20 years was less than the proportion of producers with farming experience of more than 20 years, the difference was not much. The rates for farming experience and livestock farming experience over 20 years were lower for Tackie et al. (2018), 20 and 27\%, respectively, than those for this study, but higher for Tackie et al. (2019), 76 and 56\%, respectively, compared to this study. Most of the farmers in this study are not what one might consider beginning farmers. Just as in the Tackie et al. (2019) study for Alabama, it is possible that many of these producers started farming as crop farmers but later on switched to livestock farming, added livestock farming to their enterprise mix, or may have entered livestock and crop farming at the same time.

Table 2. Farm characteristics $(\mathrm{N}=40)$

\begin{tabular}{|c|c|c|}
\hline Variable & Frequency & Percent \\
\hline \multicolumn{3}{|l|}{ Enterprises } \\
\hline Row Crops & 1 & 2.5 \\
\hline Livestock & 25 & 62.5 \\
\hline Fruits and Vegetables & 0 & 0.0 \\
\hline Multiple & 13 & 32.5 \\
\hline Other & 0 & 0.0 \\
\hline No Response & 1 & 2.5 \\
\hline \multicolumn{3}{|l|}{ Farming Experience } \\
\hline $1-5$ years & 2 & 5.0 \\
\hline $6-10$ years & 6 & 15.0 \\
\hline $11-15$ years & 6 & 15.0 \\
\hline $16-20$ years & 1 & 2.5 \\
\hline $21-25$ years & 6 & 15.0 \\
\hline $26-30$ years & 12 & 30.0 \\
\hline More than 30 years & 7 & 17.5 \\
\hline \multicolumn{3}{|c|}{ Livestock Farming Experience } \\
\hline $1-5$ years & 3 & 7.5 \\
\hline $6-10$ years & 4 & 10.0 \\
\hline $11-15$ years & 5 & 12.5 \\
\hline $16-20$ years & 5 & 12.5 \\
\hline $21-25$ years & 4 & 10.0 \\
\hline $26-30$ years & 10 & 25.0 \\
\hline More than 30 years & 9 & 22.5 \\
\hline \multicolumn{3}{|l|}{ Animal Type } \\
\hline Beef Cattle & 23 & 57.5 \\
\hline Meat Goats & 11 & 27.5 \\
\hline Both & 5 & 12.5 \\
\hline No Response & 1 & 2.5 \\
\hline
\end{tabular}




\begin{tabular}{|c|c|c|}
\hline \multicolumn{3}{|l|}{ Beef Cattle Herd Size } \\
\hline 10 or less & 5 & 12.5 \\
\hline $11-20$ & 1 & 2.5 \\
\hline $21-30$ & 6 & 15.0 \\
\hline $31-40$ & 3 & 7.5 \\
\hline $41-50$ & 2 & 5.0 \\
\hline $51-60$ & 0 & 0.0 \\
\hline $61-70$ & 3 & 7.5 \\
\hline More than 70 & 5 & 12.5 \\
\hline No Response & 4 & 10.0 \\
\hline Not Applicable & 11 & 27.5 \\
\hline \multicolumn{3}{|l|}{ Meat Goat Herd Size } \\
\hline 10 or less & 7 & 17.5 \\
\hline $11-15$ & 0 & 0.0 \\
\hline $15-20$ & 4 & 10.0 \\
\hline $21-25$ & 4 & 10.0 \\
\hline $26-30$ & 1 & 2.5 \\
\hline $31-35$ & 1 & 2.5 \\
\hline $36-40$ & 0 & 0.0 \\
\hline More than 40 & 0 & 0.0 \\
\hline No Response & 0 & 0.0 \\
\hline Not Applicable & 23 & 57.5 \\
\hline \multicolumn{3}{|l|}{ Total Acreage Owned } \\
\hline 10 acres or less & 7 & 17.5 \\
\hline $11-20$ acres & 2 & 5.0 \\
\hline $21-30$ acres & 3 & 7.5 \\
\hline $31-40$ & 2 & 5.0 \\
\hline $41-50$ acres & 4 & 10.0 \\
\hline $51-60$ acres & 2 & 5.0 \\
\hline More than 60 acres & 19 & 47.5 \\
\hline No Response & 1 & 2.5 \\
\hline \multicolumn{3}{|l|}{ Total Acreage Farmed } \\
\hline 10 acres or less & 5 & 12.5 \\
\hline $11-20$ acres & 3 & 7.5 \\
\hline $21-30$ acres & 1 & 2.5 \\
\hline $31-40$ & 3 & 7.5 \\
\hline $41-50$ acres & 2 & 5.0 \\
\hline $51-60$ acres & 4 & 10.0 \\
\hline More than 60 acres & 22 & 55.0 \\
\hline
\end{tabular}

Moreover, 58\% had beef cattle, primarily, Angus and mixed breeds (not shown in table), and 28\% had meat goats, primarily, Boer and Kiko mixed breeds (not shown in table). These breeds are quite common in the Southeast. Furthermore, the producers had small herd sizes; $30 \%$ had a beef cattle herd size of 30 heads or less and $33 \%$ had a beef cattle herd size of more than 30 heads. Correspondingly, $40 \%$ had a meat goat herd size of 30 heads or less and $3 \%$ had a meat goat herd size of more than 30 heads.

Regarding acreage owned, $30 \%$ owned 30 acres or less, $20 \%$ owned $31-60$ acres, and $48 \%$ owned over 60 acres of land. Yet, $23 \%$ farmed 30 acres or less; another 23\% farmed 31-60 acres, and 55\% farmed over 60 acres of land. More producers were on the higher ends (greater than 30 acres) of acreage owned and acreage farmed, 68 and $78 \%$, respectively, than they were on the lower ends (30 acres or less). Acreage owned and acreage farmed showed different trends. Acreage farmed exceeded acreage owned, whether in the higher than 30-acre category or higher than the 60 -acre category. The most likely interpretation could be that some of the producers may be 
renting or leasing land for their operations. These findings line up well with Tackie et al. (2019) and Tackie et al. (2018).

Table 3 presents the estimates for model 1, socioeconomic factors and their effects on acreage owned. It shows overall statistical significance of the model $(p=0.000)$, i.e., at least one or all of the socioeconomic factors jointly explain the variation in acreage owned (ACO), the dependent variable, or at least one of the socioeconomic factor regression coefficients is not equal to zero. Education and household income had statistically significant and positive effects on acreage owned, respectively, $p=0.034$ and $p=0.000$. Farming status had a statistically significant and negative effect on acreage owned, $p=0.007$. The coefficient for education means that for one unit increase in educational level, the expected ordered log odds increases by 0.782 moving from one category to the next higher category of acreage owned, all things equal. Similarly, for household income, it implies that for one unit increase in household income, the expected ordered log odds increases by 1.787 moving from one category to the next higher category of acreage owned, all things equal. Furthermore, for farming status, it means that if the farming status of a producer were to change from full-time to part-time, the expected ordered log odds decreases by 3.553 moving from one category to the next higher category of acreage owned, all things equal. Identical explanations apply to the other variables in model 1 . In short, farming status, education, and household income contribute greatly to acreage owned. The more there are part-time farmers, the less the acreage owned. The higher the educational level and household income, the larger the acreage owned.

Table 3. Estimates for socioeconomic factors and their effects on acreage owned

\begin{tabular}{lll}
\hline Variable & $\beta$ & $\mathrm{P}$ \\
\hline Farming status & $-3.553^{* * * *}$ & 0.007 \\
Gender & -0.104 & 0.920 \\
Race/ethnicity & -0.123 & 0.907 \\
Age & -0.687 & 0.163 \\
Education & $0.782^{* *}$ & 0.034 \\
Household Income & $1.787^{* * *}$ & 0.000 \\
\hline Chi-square & $30.322^{* * *}$ & \\
\hline
\end{tabular}

Note. $* * *$ Significant at $1 \% ; * *$ Significant at $5 \%$.

The findings are not a surprise. For example, for farming status, it is expected that if there are more part-time producers, all things equal, they would more likely own less land. This is because, generally, part-time producers have a primary occupation elsewhere, which normally takes more of their time, and therefore, might not want to own more acreage. For education, it stand to reason that as people get more education, all things equal, they would be more knowledgeable and be able to ascertain better information to own more acreage. The result on education is in agreement with Tackie et al. (2019) for Alabama, who also reported that education had a positive and statistically significant effect on acreage owned. Also, for household income, it is not far fectched to expect that as people get more financial resources, all things equal, they would be able to own more acreage, because it is obvious that more financial resources make access to assets easier. Therefore, such persons would be more able to own more acreage. Gender, race/ethnicity, and age were statistically insignificant. Despite this, gender, race/ethnicity had the expected signs; however, age had the unexpected sign. For the former, this means that female producers and Black producers were less likely to own more acreage than male producers and White producers. Correspondingly, for the latter, it means that older producers were less likely to own more acreage than younger producers. The negative relationship between acreage owned and age was unexpected. It is possible that older producers were selling land or transferring land by using other means.

Table 4 depicts the estimates for model 2, socioeconomic factors and their effects on acreage farmed. It also reveals overall statistical significance of the model $(p=0.004)$, i.e., at least one or all of the socioeconomic factors jointly explain the variation in acreage farmed (ACF), the dependent variable, or at least one of the socioeconomic factor regression coefficients is not equal to zero. Here as well, household income had a statistically significant and positive effect on acreage farmed, $p=0.009$. Also, again, farming status had a statistically significant and negative effect on acreage farmed, $p=0.040$. The coefficient for household income means that for one unit increase in household income, the expected ordered log odds increases by 0.967 moving 
from one category to the next higher category of acreage farmed, all things equal. As before, for farming status, it means that if the farming status of a producer were to change from full-time to part-time, the expected ordered log odds decreases by 2.421 moving from one category to the next higher category of acreage farmed, all things equal. Similar explanations apply to other variables in model 2. Consequently, it implies farming status and household income contribute greatly to acreage farmed. The more there are part-time producers, the less the acreage farmed. The higher the household income, the larger the acreage farmed.

Table 4. Estimates for socioeconomic factors and their influence on acreage farmed

\begin{tabular}{lll}
\hline Variable & $\beta$ & $P$ \\
\hline Farming Status & $-2.421^{* *}$ & 0.040 \\
Gender & 1.404 & 0.220 \\
Race/ethnicity & 0.468 & 0.655 \\
Age & -0.124 & 0.806 \\
Education & 0.398 & 0.213 \\
Household Income & $0.967^{* * *}$ & 0.009 \\
\hline Chi-square & $18.906^{* * *}$ & \\
& $(P=0.004)$ & \\
\hline
\end{tabular}

Note. $* * *$ Significant at $1 \% ; * *$ Significant at $5 \%$.

The findings, once again, are not a surprise. Indeed, the argument made for acreage owned, holds for acreage farmed. That is, for farming status, it is expected that the more there are part-time producers, all things equal, the less the acreage that they would farm. The explanation, as before, is that part-time producers have limited time to focus on production on farm, as their time is also occupied somewhere else, in their primary occupation. For household income, it is obvious that as people get more financial resources, all things equal, they would be able to farm more acreage. This is because, as in the case of acreage owned, these producers would be able to acquire more acreage, and therefore, farm more acreage. Although this finding is not totally in agreement with Tackie et al. (2019) for Alabama, in terms of significance, it makes intuitive sense that income would have a positive and statistically significant effect on acreage farmed. In the aforementioned study, although there was no statistical significance, income had a positive relationship with acreage farmed. Gender, race/ethnicity, age, and education were statistically insignificant. Gender, race/ethnicity, and education had the expected signs. However, once again, age did not have the expected sign. This implies that male producers, White producers, and producers with higher educational levels were more likely to farm larger acreages than female producers, Black producers, and producers with lower education levels. It is possible that education was not significant in this case, because although those with higher levels of education farmed more acreage, it was not large enough to have a great impact on acreage farmed. Again, the negative relationship between acreage farmed and age was unexpected. It is possible that older producers were reducing acreage on which they farmed.

\section{Conclusion}

This study examined the effect of socioeconomic factors on acreage owned and acreage farmed. Particularly, it identified and described socioeconomic and other factors, and estimated the extent to which socioeconomic factors influenced acreage owned and acreage farmed. The data were obtained using a questionnaire, and analyzed using descriptive statistics and ordinal logistic regression analysis. The results revealed that, a majority of the respondents were full-time producers; were females; were middle-aged or older; had some college or lower educational level, and had an annual household income of more than $\$ 40,000$. Additionally, a majority had farming experience of 30 years or less; had livestock faming experience of 30 years or less; had small livestock herd sizes; had acreage owned of more than 60 acres, and had acreage farmed of more than 60 acres (48 versus $55 \%)$.

The ordinal logistic regression analyses showed that selected socioeconomic factors, namely, farming status, education, and household income had statistically significant effects on acreage owned; and farming status and household income had statistically significant effects on acreage farmed. Although other factors, gender, race/ethnicity, and age did not have significant effects on acreage owned, gender and race/ethnicity had the expected signs. However, age did not have the expected sign. What is more, gender, race/ethnicity, age, and education did not have significant effects on acreage farmed. Whereas, gender, race/ethnicity, and education had the expected signs, age did not. 
The findings suggest that, farming status, education, and household income are important to farm size, at least in the study area. It is conceivable that other factors may also be important to farm size, but that was not obvious in this study. A major contribution of this study is that socioeconomic factors matter in acreage owned and acreage farmed by small livestock producers in the study area. That said, such factors should be taken into account in designing programs for small producers. A corollary is that since most of the producers are very small farmers, specific programs should be designed for them to enhance their productivity. This study has laid an additional "ground work" for further studies in the subject area, considering Tackie et al. (2019). As in that study, future studies may include, but not limited to, replicating this study, or using a larger sample size, and/or focusing on a larger geographical area. Hopefully, as future studies are refined, a clearer message or trajectory will be revealed.

\section{Acknowledgements}

This study was funded by USDA National Institute of Food and Agriculture, Agriculture and Food Research Initiative Competitive Grant, 2013-68004-20357.

\section{References}

Anigbogu, T. U., Agbosi, O. E., \& Okoli, I. M. (2015). Socioeconomic factors influencing agricultural production among cooperative farmers in Anambra State, Nigeria. International Journal of Academic Research in Economics and Management Studies, 4(3), 43-58. https://doi.org/10.6007/IJAREMS/ v4-i3/1876

Banterle, A., \& Cavaliere, A. (2009). The social and economic determinants of obesity: An empirical study in Italy. Presented at the $113^{\text {th }}$ EAAE Seminar, September 3-6, 2009, Chania, Crete, Greece.

Gujarati, D. N., \& Porter, D. C. (2009). Basic Econometrics (5th ed.). New York, New York: McGraw Hill Irwin.

Helfand, S. M., \& Levine, E. S. (2004). Farm size and determinants of productive efficiency in the Brazilian Center-West. Agricultural Economics, 31(2-3), 241-249. https://doi.org/10.1111/j.1574-0862.2004. tb00261.x

Khalil, C. A., Conforti, P., Ergin, I., \& Gennari, P. (2017). Defining small scale food producers to monitor target 2.3 of the 2030 Agenda for sustainable development. (Working Paper Series ESS/17-2). FAO Statistics Division, Rome, Italy.

LPELC. (2019). USDA Small farm definitions. Retrieved December 13, 2019, from https://lpelc.org/usda-smallfarm-definitions

MacDonald, J. M., Hoppe, R., \& Newton, D. (2017). Tracking Consolidation in U.S. Agriculture. Washington, DC: USDA ERS.

Maixner, E., \& Wyant, S. (2019). Big Changes ahead in land ownership, and farm operations? Retrieved November 30, 2019, from https://www.agri-pulse.com/articles/11869-big-changes-ahead-in-land-ownership -and-farm-operators

Mburu, S., Ackello-Ogutu, C., \& Mulwa, R. (2014). Analysis of economic efficiency and farm size: A case study of wheat farmers in Nakuru District, Kenya. Economic Research International. https://doi.org/10.1155/ 2014/802706

Newton, D. J. (2014). Working the land with 10 acres: Small acreage farming in the United States (Economic Information Bulletin Number 123). Washington, DC: USDA ERS. https://doi.org/10.2139/ssrn.2502872

Richardson, J. W., \& Condra, G. D. (1981). Farm size evaluation in El Paso Valley: A survival/success approach. American Journal of Agricultural Economics, 63(3), 430-437. https://doi.org/10.2307/1240533

Sheng, Y., Zhao, S., Nossal, K., \& Zhang, D. (2015). Productivity and farm size in Australian Agriculture: Reinvestigating the returns to scale. The Australian Journal of Agricultural Economics, 59(1), 16-38.

Tackie, D. N. O., Adu-Gyamfi, A., Bartlett, J. R., McKenzie-Jakes, A., \& Perry, B. J. (2018). An analysis of the characteristics and practices of selected Florida small livestock producers: A focus on economics and marketing. Journal of Economics and Sustainable Development, 9(14), 132-149.

Tackie, D. N. O., Bartlett, J. R., \& Nunoo, N. I. (2019). Do socioeconomic factors matter in acreage owned and acreage farmed by small livestock producers in Alabama? Journal of Agricultural Science, 11(10), 1-13. https://doi.org/10.5539/jas.v11n10p1 
Thompson, E. Jr. (1986). Small is bountiful: The importance of small America. Washington, DC: American Farmland Trust.

USDA NASS. (2016). 2012 Census of Agriculture Highlights (Publication Number ACH12-34). USDA NASS, Washington DC.

USDA NASS. (2019a). 2017 Census of Agriculture Highlights: Farms and Farmland (Publication Number ACH17-3). USDA NASS, Washington DC.

USDA NASS. (2019b). 2017 Census of Agriculture Highlights: Farm Economics (Publication Number ACH17-1). USDA NASS, Washington DC.

Van Zyl, J., Binswanger, H., \& Thirtle, C. (1995). The relationship between farm size and efficiency in South African Agriculture. Policy Research Working Paper 1548. Washington DC: Agriculture and Natural Resources Department, The World Bank.

Weiss, C. R. (1999). Farm growth and survival: Econometric evidence for individual farms in Upper Austria. American Journal of Agricultural Economics, 81(1), 103-116. https://doi.org/10.2307/1244454 


\section{Appendix A}

Variable definitions and descriptions of data for the models $(\mathrm{N}=29)$

\begin{tabular}{|c|c|c|c|}
\hline Variable & Description & Mean & Standard Deviation \\
\hline \multirow{2}{*}{ Farming status } & $1=$ full-time & \multirow{2}{*}{1.52} & \multirow{2}{*}{0.51} \\
\hline & $2=$ part-time & & \\
\hline \multirow{2}{*}{ Gender } & $1=$ male & \multirow{2}{*}{0.38} & \multirow{2}{*}{0.49} \\
\hline & $0=$ female & & \\
\hline \multirow{2}{*}{ Race/ethnicity } & $1=$ Black & \multirow{2}{*}{1.59} & \multirow{2}{*}{0.50} \\
\hline & $2=$ White & & \\
\hline \multirow{6}{*}{ Age } & $1=20-24$ & \multirow{6}{*}{5.07} & \multirow{6}{*}{1.13} \\
\hline & $2=25-34$ & & \\
\hline & $3=35-44$ & & \\
\hline & $4=45-54$ & & \\
\hline & $5=55-64$ & & \\
\hline & $6=65$ or above & & \\
\hline \multirow{5}{*}{ Education } & $1=$ high school or less & \multirow{5}{*}{3.17} & \multirow{5}{*}{1.65} \\
\hline & $2=$ two-year/technical & & \\
\hline & $3=$ some college & & \\
\hline & $4=$ college degree & & \\
\hline & $5=$ post-graduate/professional & & \\
\hline \multirow{7}{*}{ Household income } & $1=\$ 10,000$ or less & \multirow{7}{*}{5.83} & \multirow{7}{*}{1.42} \\
\hline & $2=\$ 10,001-20,000$ & & \\
\hline & $3=\$ 20,001-30,000$ & & \\
\hline & $4=\$ 30,001-40,000$ & & \\
\hline & $5=\$ 40,001-50,000$ & & \\
\hline & $6=\$ 50,001-60,000$ & & \\
\hline & $7=$ more than $\$ 60,000$ & & \\
\hline \multirow{7}{*}{ Acreage owned } & $1=10$ or less acres & \multirow{7}{*}{4.66} & \multirow{7}{*}{2.54} \\
\hline & $2=11-20$ acres & & \\
\hline & $3=21-30$ acres & & \\
\hline & $4=31-40$ acres & & \\
\hline & $5=41-50$ acres & & \\
\hline & $6=51-60$ acres & & \\
\hline & $7=$ More than 60 acres & & \\
\hline \multirow{7}{*}{ Acreage farmed } & $1=10$ or less acres & \multirow{7}{*}{5.21} & \multirow{7}{*}{2.47} \\
\hline & $2=11-20$ acres & & \\
\hline & $3=21-30$ acres & & \\
\hline & $4=31-40$ acres & & \\
\hline & $5=41-50$ acres & & \\
\hline & $6=51-60$ acres & & \\
\hline & $7=$ More than 60 acres & & \\
\hline
\end{tabular}

\section{Copyrights}

Copyright for this article is retained by the author(s), with first publication rights granted to the journal.

This is an open-access article distributed under the terms and conditions of the Creative Commons Attribution license (http://creativecommons.org/licenses/by/4.0/). 